\title{
Ameliorative effect of certolizumab on experimentally induced acute necrotic pancreatitis in rats
}

Mehmet Ali Kosekli1

(iD) Özkan Herek ${ }^{2}$

D Özlem Ozmen ${ }^{3}$

Sima Sahinduran ${ }^{4}$

\begin{abstract}
1. Hakkari State Hospital, Clinic of Gastroenterology, Hakkari, Turkey 2. Department of Children Surgery, Faculty of Medicine, Pamukkale University, Denizli, Turkey 3. Department of Pathology, Faculty of Veterinary Medicine, Mehmet Akif Ersoy University, Burdur, Turkey 4. Department of Internal Medicine, Faculty of Veterinary Medicine, Mehmet Akif Ersoy University, Burdur, Turkey
\end{abstract}

http://dx.doi.org/10.1590/1806-9282.65.2.204

\begin{abstract}
SUMMARY
OBJECTIVE: The effects of Certolizumab, a pegylated monoclonal antibody to tumor necrosis factor $\alpha$, on experimentally induced acute pancreatitis (AP) were examined.

METHODS: Thirty-six Wistar Albino male rats were randomly divided into four groups. Group I was the control group and no medication administered to this group. Group // was the Certolizumab group, and $100 \mathrm{ml} / \mathrm{kg}$ serum physiologic administered into the biliopancreatic duct and a single dose of $10 \mu \mathrm{g}$ Certolizumab was simultaneously administered intraperitoneally. Acute pancreatitis was induced with a retrograde injection of $3 \%$ Na taurocholate into the common biliopancreatic duct in the study (Group III) and treatment (Groups IV) groups. Rats were sacrificed 72 hours later. Serum amylase, lipase, lactate dehydrogenase activities, along with pancreatic histopathology, were examined.
\end{abstract}

RESULTS: Certolizumab treatment significantly decreased serum amylase, lipase, and LDH levels; histopathologically edema, hemorrhage, parenchymal necrosis, fat necrosis, and infiltration scores; immunohistochemically MDA, MPO, TNF- $\alpha$ and Caspase-3 activity.

CONCLUSION: The results support the idea that certolizumab might be beneficial for the severity of $A P$.

KEYWORDS: Pancreatitis, acute necrotizing. Certolizumab Pegol. Rats.

\section{INTRODUCTION}

Acute pancreatitis (AP) is one of the most common diseases and a huge threat to human health with limited specific therapy. With many complications, its mortality rate ranges from $11.8 \%$ to $25 \% .^{1}$ Clinically, it is characterized by edematous and necrotic features. From all of the gastrointestinal system diseases, AP is one of the conditions with most frequent hospital- ization. The incidence of the disease is reported to be 4-41/100.000 ${ }^{2}$ and is increasing alongside with obesity and bile stone incidence; however, mortality rates did not decrease in the same ratio. ${ }^{3}$

To understand the pathogenesis of acute pancreatitis, experimental models are essential. At the pathogenesis of AP, early trypsinogen activation and 
the nuclear factor- Kappa B (NF-kB) activation are the most common pathways. Then, inflammatory mediators and cytokines, such as TNF, play a role in local and systemic damage. TNF, which secretes immune and non-immune cells such as macrophages, $\mathrm{T}$ cells, mast cells, has been shown to have a role in acute pancreatitis. Blocking the TNF can minimize pancreatic damage. ${ }^{4,5}$ Given the importance of TNF- $\alpha$ in the pathogenesis of acute pancreatitis, investigators have regarded blocking the action of this mediator as an attractive treatment option.

Certolizumab is a polyethylene glycolic covalent linked to a monovalent Fab1 antibody fragment. Certolizumab, an anti-TNF monoclonal antibody, binds to the soluble and transmembrane forms of TNF- $\alpha$ not including the Fc fragment. It is an approved treatment for rheumatoid arthritis, psoriasis and Crohn disease. ${ }^{6,7}$

This study aims to examine the effect of the new Certolizumab and if it has a different action than anti-TNF- $\alpha$ in experimentally Na-taurocholate induced acute necrotic pancreatitis model in rats.

\section{METHOD}

The experiment was approved by the Committee of Institutional Animal Use and Care of the Pamukkale University and was performed in accordance with the National Institutes of Health Guidelines for the Care and Handling of Animals. Rats were kept in the Pamukkale University Experimental Animals Laboratory, which is internationally accredited for its suitable conditions.

\section{Animals}

Wistar Albino male rats weighing 180-220g were used for this study. The rats were fed standard rat chow and tap water ad libitum and housed in a laboratory with automatically controlled temperature and humidity throughout the study. The physical condition of each rat was assessed daily for any obvious clinical symptoms.

\section{Experimental Design}

Thirty-six rats were randomly allocated into 4 groups of 9 animals. The rats were kept in groups of 3 in a cage before the study. Then, they were kept individually in a cage during the experiment. All rats underwent laparotomy under $60-100 \mathrm{mg} /$ kg ketamine anesthesia (Ketalar; EczacNbasN War-
ner-Lambert, Istanbul, Turkey). The abdomen was opened via a midline excision to manipulate the $\mathrm{du}-$ odenum and the biliopancreatic duct. The duodenal wall was punctured on the antimesenteric side with a 27-gauge catheter (inner diameter, $7 \mathrm{~mm}$; introcan-w; Braun, Melsungen, Germany) 2-3 cm far from the duodenal opening of the biliary canal. The catheter was advanced into the papilla of Vater and fixed to the duodenal wall with 6-0 Prolene. For inducing AP, the pancreatic canal was approached, and 3\% Na-taurocholate (Sigma-Aldrich, Steinheim, Germany) or serum physiologic $(1 \mathrm{~mL} / \mathrm{kg})$ was infused according to the retrograde ductal injection model. ${ }^{8}$ Both Na-taurocholate and physiological saline were infused at a pressure of $30 \mathrm{~mm} \mathrm{Hg}$ controlled by a mercury manometer. Only catheters that were properly placed in the rats were included the study. The abdomen was closed in aseptic conditions, and $1 \mathrm{ml} / 100$ gr physiological saline was given for fluid replacement.

\section{Study Protocol:}

Group 1 (Control group): Physiological saline alone was administered to the common biliopancreatic duct. No drug was given this group.

Group 2 (Certolizumab group): Physiologic saline $(100 \mathrm{ml} / \mathrm{kg})$ was given via the common biliopancreatic duct; a single dose of Certolizumab (Cimzia ${ }^{\circ}$ -UCB-USA) was simultaneously administered at 10 $\mathrm{\mu g}$ intraperitoneally.

Group 3 (Na-Taurocholate group): Acute pancreatitis was induced with an injection of 3\% Na-taurocholate (T9034, Sigma- Aldrich, Steinheim, Germany) into the common biliopancreatic duct; physiological saline was simultaneously administered at $100 \mathrm{~mL} /$ $\mathrm{kg}$ intraperitoneally.

Group 4 (Treatment group): Acute pancreatitis was induced with an injection of $3 \%$ Na-taurocholate into the common biliopancreatic duct, and Certolizumab was simultaneously administered at $10 \mu \mathrm{g}$ intraperitoneally.

After 72 hours inducing the pancreatitis, rats were anesthetized using $10 \mathrm{mg} / \mathrm{kg}$ xylazine hydrochloride (Rhompun ${ }^{\circledR}$, Bayer, Istanbul) and $60 \mathrm{mg} / \mathrm{kg}$ ketamine (Ketalar ${ }^{\circledR}$, Eczacıbası Warner-Lambert, Istanbul). Intracardiac blood was drawn under anesthesia. Then, the rats euthanatized, and pancreatic tissue samples were collected immediately after their death. Tissue samples were put into $10 \%$ formalin solution. Serum amylase, lactate dehydrogenase (LDH), malondial- 
dehyde (MDA), and myeloperoxidase (MPO) enzyme activities were assessed.

\section{Histopathologic Evaluation}

Pancreatic tissue samples were put into 10\% formalin, routinely processed, paraffin embedded, and then stained with hematoxylin and eosin to be interpreted using light microscopy. Histopathologic changes were graded in a blinded manner. The examination and scoring of the pancreatic tissues were evaluated by an experienced pathologist from another university. For this purpose, some parameters were determined by the adoption of those indicated in the references and our previous study. ${ }^{9-11}$ The severity of pancreatitis was documented by scoring edema, hemorrhages, leukocyte infiltration, parenchymal necrosis, and fatty tissue necrosis. Each criterion was graded on a scale of 0 to 3 . Edema and hemorrhage were assessed according to their location. Leukocyte infiltration and parenchymal necrosis were evaluated according to the number of the lobules involved, and fat necrosis was scored based on its occurrence in the peripancreatic tissue. Data from each animal were statistically analyzed.

\section{Immunohistochemical evaluation}

All pancreas samples were immunostained with malondialdehyde (MDA) [anti-malondialdehyde antibody (ab6463), Abcam, Cambridge, UK, 1/100 dilution], myeloperoxidase (MPO) [anti-myeloperoxidase antibody (ab45977), Abcam, Cambridge, UK, 1/100 dilution], TNF- $\alpha$ [anti-TNF alpha antibody [52B83] (ab66579), Abcam, Cambridge, UK, 1/100 dilution] and Caspase-3 antibody [anti-Caspase 3 antibody (ab4051), Abcam, Cambridge, UK, 1/100 dilution] using a routine streptoavidin-biotin peroxidase technique for evaluating MDA, Myeloperoxidase, TNF- $\alpha$ and apoptotic activity of the cells. A Novostain Universal Detection Kit (ready to use) [Abbiotech, San Diego, CA,] was used as a secondary antibody according to the manufacturer' instruction.

For evaluation of immunoreactivity, 10 randomly chosen microscopic fields (X40) near the necrotic areas or pancreatic duct for controls were examined for each slide; 100 cells were counted, a percentage of positive cells was calculated, and statistical analysis was performed.

\section{Biochemical analysis}

Blood samples were immediately centrifuged at $3000 \mathrm{~g}$ for $10 \mathrm{~min}$ at room temperature and stored $-80^{\circ} \mathrm{C}$ until examination for LDH, amylase, and lipase levels. Serum LDH, lipase, and amylase activity was measured using a VetTest commercial kit by IDEXX (Westbrooke, Maine).

\section{Statistical Analysis}

An one-way analysis of variance (ANOVA) was applied to evaluate the biochemical and histopathological findings and for statistical comparisons between the experimental groups. A significance assessment was carried out using the Duncan test. The results

TABLE I. MEAN STATISTICAL VALUES OF EACH HISTOPATHOLOGICAL, IMMUNOHISTOCHEMICAL, AND BIOCHEMICAL RESULTS OF THE STUDY GROUPS

\begin{tabular}{|c|c|c|c|c|c|}
\hline \multirow[b]{2}{*}{ Parameter } & \multicolumn{4}{|l|}{ Groups } & \multirow[b]{2}{*}{ P value } \\
\hline & Control & Certolizumab & $\mathrm{Na}$-Taurocholate & $\begin{array}{l}\text { Na-Taurocholate + } \\
\text { Certolizumab }\end{array}$ & \\
\hline Edema & $0.00 \pm 0.00^{a}$ & $0.42 \pm 0.20^{a}$ & $1.85 \pm 0.40^{c}$ & $1.00 \pm 0.21^{\mathbf{b}}$ & $<0.001^{\star \star \star}$ \\
\hline Hemorrhage & $0.00 \pm 00^{a}$ & $0.14 \pm 0.144^{a}$ & $1.71 \pm 0.18^{c}$ & $0.85 \pm 0.14^{b}$ & $<0.001^{\star \star \star}$ \\
\hline $\begin{array}{l}\text { Parenchymal } \\
\text { necrosis }\end{array}$ & $0.00 \pm 0.00^{a}$ & $0.28 \pm 0.18^{a}$ & $1.71 \pm 0.35^{c}$ & $1.00 \pm 0.21^{\mathbf{b}}$ & $<0.001^{\star \star \star}$ \\
\hline Fat necrosis & $0.00 \pm 0.00^{a}$ & $0.00 \pm 0.00^{a}$ & $1.28 \pm 0.42^{\mathbf{b}}$ & $0.57 \pm 0.29^{a}$ & $<0.01^{\star *}$ \\
\hline $\begin{array}{l}\text { Leukocyte infil- } \\
\text { tration }\end{array}$ & $0.00 \pm 0.00^{a}$ & $0.42 \pm 0.20^{a}$ & $1.57 \pm 0.36^{c}$ & $1.00 \pm 0.37^{\mathbf{b}}$ & $<0.001^{\star \star \star *}$ \\
\hline MDA & $0.37 \pm 0.26^{a}$ & $0.57 \pm 0.20^{a}$ & $2.00 \pm 0.30^{\mathbf{b}}$ & $0.85 \pm 0.26^{a}$ & $<0.001^{\star \star \star}$ \\
\hline $\mathrm{TNF}-\alpha$ & $0.37 \pm 0.74^{a}$ & $0.37 \pm 0.51^{\mathbf{a}}$ & $2.42 \pm 0.78^{c}$ & $0.85 \pm 0.69^{b}$ & $<0.001^{\star \star \star}$ \\
\hline MPO & $0.37 \pm 0.18^{a}$ & $0.42 \pm 0.20^{a}$ & $1.42 \pm 0.20^{\mathbf{b}}$ & $1.14 \pm 0.26^{b}$ & $<0.01^{\star *}$ \\
\hline Caspase-3 & $0.62 \pm 0.32^{\mathbf{a}}$ & $0.71 \pm 0.18^{a}$ & $2.00 \pm 0.30^{b}$ & $0.85 \pm 0.26^{a}$ & $<0.01^{\star \star}$ \\
\hline $\mathrm{LDH}(\mathrm{U} / \mathrm{L})$ & $746.33 \pm 38.27^{a}$ & $984.28 \pm 88.69$ a & $3915.28 \pm 183.37^{c}$ & $1984.57 \pm 278.67^{\mathbf{b}}$ & $<0.001^{* * *}$ \\
\hline Amylase (U/L) & $1044.75 \pm 52.45^{a}$ & $1126.28 \pm 188.13$ a & $2807.28 \pm 147.17^{\mathbf{b}}$ & $1430.85 \pm 135.12 \mathbf{a}^{\mathbf{a}}$ & $<0.001^{\star \star \star}$ \\
\hline Lipase (U/L) & $41.00 \pm 8.05^{a}$ & $68.00 \pm 15.68^{a}$ & $342.42 \pm 47.69^{c}$ & $166.28 \pm 19.28^{\mathbf{b}}$ & $<0.001^{* * *}$ \\
\hline
\end{tabular}




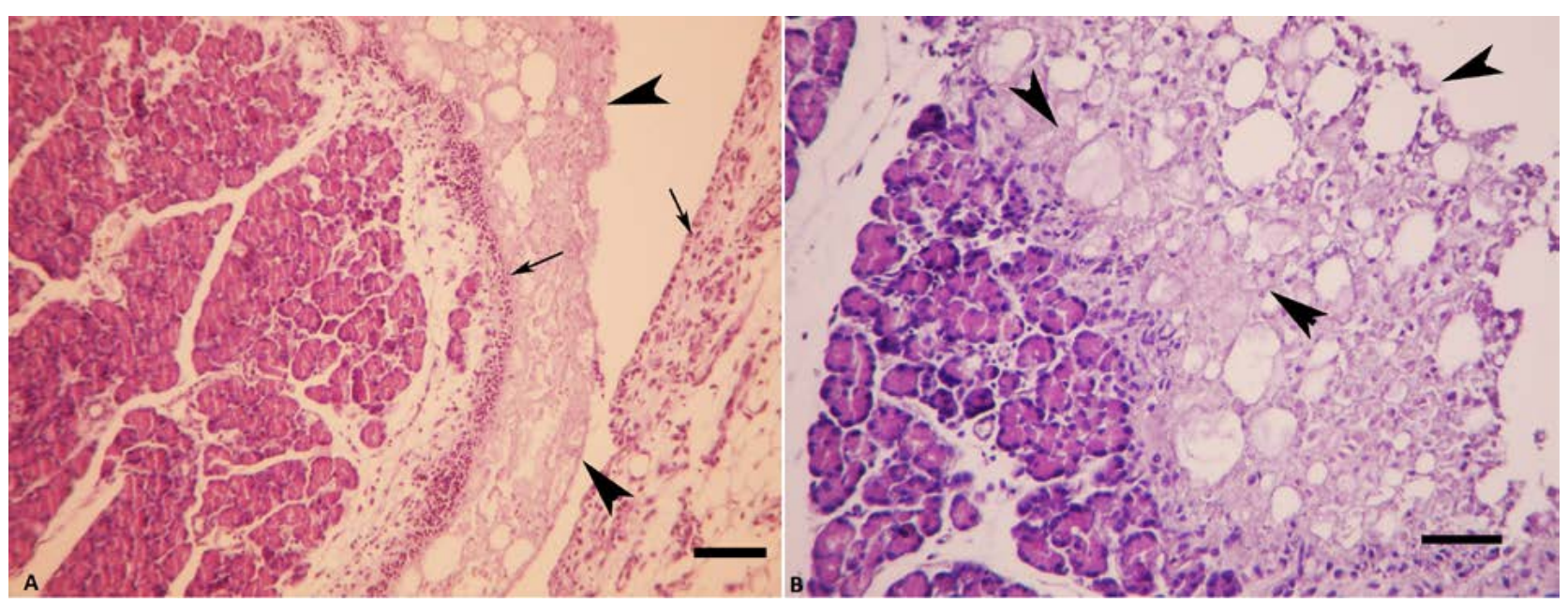

FIG. I: A. Acute necrotic pancreatitis, severe necrosis (arrowheads) and numerous neutrophil leukocytes (arrows) in the pancreas in a rat from the $\mathrm{Na}$-taurocholate group, $\mathrm{HE}, \mathrm{Bar}=100 \mu \mathrm{m}$. B. Acute necrotic pancreatitis, severe necrosis (arrowheads) in the pancreas in a rat from the Na-taurocholate group, Bar=200 $\mu \mathrm{m}$.

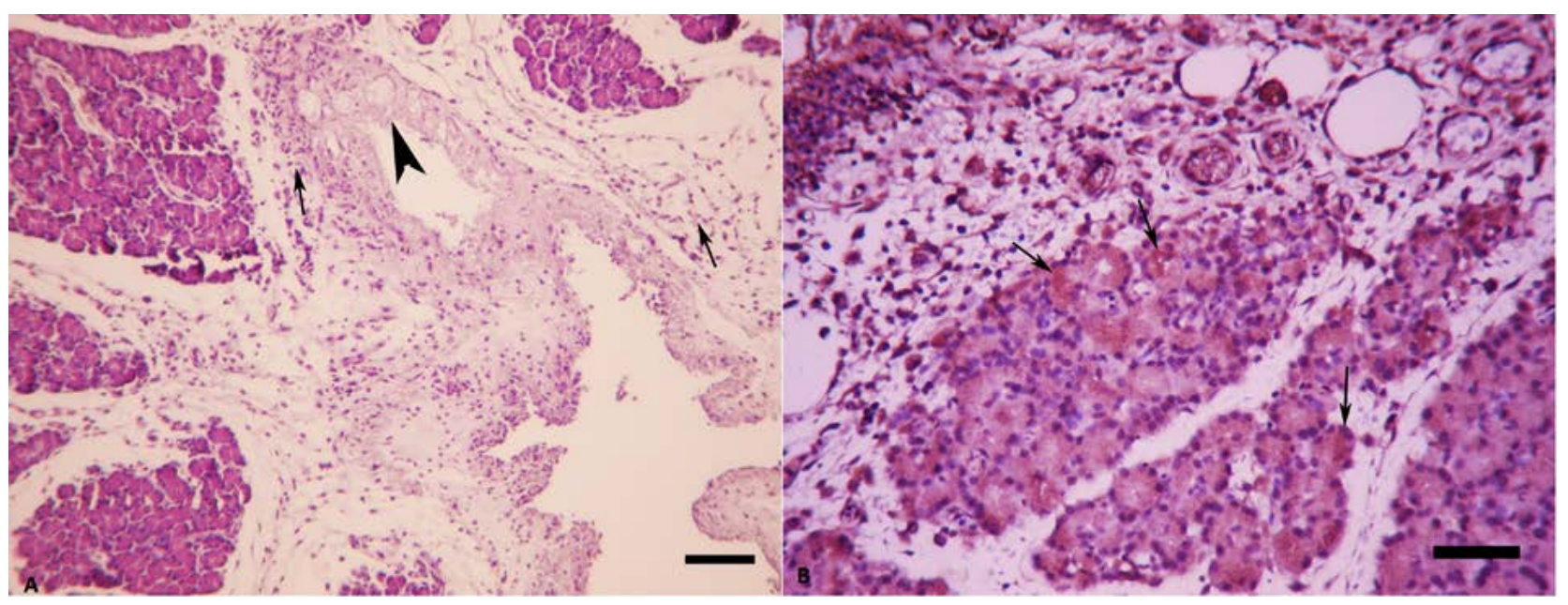

FIG. II: A. Slight necrosis (arrowhead) and neutrophil leukocyte infiltrations in a rat from the Na-taurocholate + certolizumab group, HE, Bar=100 $\mu \mathrm{m}$. B. Marked caspase-3 immunoreaction in acinar cells (arrows) of the pancreas in a rat from the Na-tau-

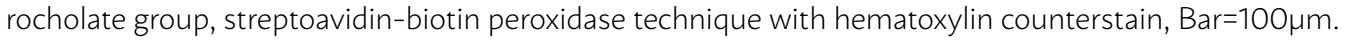

were expressed as mean \pm SD. The values were considered to be statistically significant when $\mathrm{P}<0.05$. The statistical analysis was done with SPSS 13.0 software (SPSS Inc, Chicago, Ill).

\section{RESULTS}

The most severe clinical and pathological symptoms were observed in the Na-taurocholate group and characterized by severe necrotizing pancreatitis, marked retroperitoneal edema, and hemorrhagic ascites.

In the control group and certolizumab group, the normal glandular architecture was preserved. Na-taurocholate induced pancreatic damage was evident by increased edema, neutrophil leukocyte infiltration, hemorrhage and necrosis in both parenchymal and fat tissues (Fig.1). These lesions were observed in Na-taurocholate and Na-taurocholate + certolizumab groups but were more severe in the Na-taurocholate group. However, treatment with certolizumab reduced histopathological lesions (Fig.2). The statistical analysis results of serum LDH, amylase and lipase levels in study groups are shown in Table 1.

Immunohistochemically-marked increases were observed in MDA, MPO, TNF- $\alpha$ and Caspase- 3 expression in the Na-taurocholate group (Fig.2). Certolizumab treatment showed an ameliorative effect in the Na-taurocholate + certolizumab groups.

Serum amylase, lipase, and LDH levels were higher in the Na-taurocholate group and Na-taurocholate + certolizumab groups but levels were markedly higher in the Na-taurocholate group. Amylase, lipase and LDH activities were according to the refer- 
ence values in the control group. However, a slight increase was observed in the Na-taurocholate + certolizumab group.

\section{DISCUSSION}

AP is a systemic inflammatory disease, characterized by acute abdominal pain associated with an increase in serum amylase and lipase levels. ${ }^{12,13}$ It is a common condition of which clinical manifestations may range from a mild, self-limiting disease to an inflammatory process with life-threatening complications. The development of pancreatic necrosis results in a dramatic increase in mortality in AP patients. ${ }^{14}$ There are no specific therapies for acute pancreatitis, and the treatment remains largely supportive. A better comprehension of the inflammatory effects, which play a major role in the pathogenesis of the disease, appears necessary for the development of new therapeutic strategies. In the present study, the pathological changes and biochemical results in the treated group improved. In this study, we examined the effect of the anti-TNF- $\alpha$ agent certolizumab for the treatment of acute necrotic pancreatitis.

TNF- $\alpha$, a cytokine, mediates a broad spectrum of host responses to stress and injury and it is strongly involved in many deleterious events in the course of AP. ${ }^{15}$ Our results directly evidence that TNF- $\alpha$ plays a pivotal role in Na-taurocholate induced pancreatitis and that it may be a novel target of therapeutic applications for treating pancreatic inflammation. This study showed that TNF- $\alpha$ markedly increased in pancreatic tissue in AP, and anti-TNF- $\alpha$ treatment caused marked amelioration of both pathological and biochemical findings.

Pancreatic exocrine secretion disruption is an important feature of AP because there has been reported an evident alteration in pancreatic secretory response in pancreatic acini after taurocholate infusion. A marked increase in amylase release during experimental pancreatitis has previously been demonstrated commonly, ${ }^{11,16-18}$ suggesting that this increase is not due to a physiological secretory response but to enzyme release from damaged cells. ${ }^{16}$ In this study, we also observed a marked increase in pancreatic lipase and amylase levels in serum in 72 hours after inducing pancreatitis. At the same time, pancreatic tissue destruction and oxidative tissue stress and cytokine level increase were observed immunohistochemically.
Certolizumab neutralized both transmembrane and soluble TNF by binding to p55 and p75 TNF-a receptors in vitro. ${ }^{6}$ Since Fc fraction was not included, Certolizumab mineralized the Fc mediated complement dependent cytotoxicity (CDC) and antibody dependent cell-mediated cytotoxicity (ADCC). While adalimumab, infliximab, and etanercept induced CDC and ADCC in vitro, certolizumab did not have this effect. ${ }^{7}$ Certulizumab does not transfer from the placenta. $^{19}$

During the inflammatory process of acute pancreatitis, PPAR - gamma activation and the early activation of trypsinogen the acinus are the main pathways. Via the inflammatory process triggered by various factors, many mediators appeared. TNF is one of these mediators. Due to the TNF release in the early stages, neutrophils are activated and released oxygen free radicals that caused lipid peroxidation, cellular swelling, and cell death. ${ }^{20,21}$ Experimental studies have shown that by blocking TNF, inflammation can be minimized and pancreatic damage limited., ${ }^{4,5}$ Pancreatic tissue damage in the treatment group given certolizumab was significantly lower than the group that received treatment. Because the TNF- $\alpha$ is responsible for both local and systemic effects in pancreatitis, the inhibition of TNF- $\alpha$ is thought to diminish local and systemic complications. Indeed, Hughes et al. ${ }^{5}$, showed that TNF blockade in acute pancreatitis decreased the complications associated with pancreatitis. Norman et al.15, reported that soluble TNF- $\alpha$ inhibition could decrease the severity of experimental pancreatitis and mortality but not influence the pancreatic vacuolization, necrosis, and inflammatory cell infiltration. Oruc et al. ${ }^{22}$ showed that infliximab has anti-inflammatory effects in an edematous and necrotizing pancreatitis model. In the same study, infliximab significantly reduced parenchymal fat necrosis but did not affect the mortality rate, pancreatic edema, and neutrophil activity. In our study, certolizumab showed a positive effect on all of the histopathological parameters. A possible reason for these differences in the results might be due to a difference in efficiency between the different molecules used in the studies. Yilmaz et al.11, reported that a soluble TNF receptor fusion protein etanercept can cause amelioration on histopathological scores and biochemical parameters on Na-taurocholate induced necrotizing pancreatitis model. The study showed that etanercept causes a decrease in pancreatic fibrosis in the long-term. In another simi- 
lar study, adalimumab treatment on necrotizing pancreatitis has been described to have improved histological lesion scores, biochemical parameters, and tissue damage indicators. ${ }^{11,22}$ In the last 3 studies, infliximab, etanercept, and adalimumab had a positive effect on the serum marker of pancreatic injury. Our findings are also similar to them.

An intracellular calcium concentration increase can cause acinar cell calcium signaling defects, intracellular trypsinogen activation, and at least leads to vacuolization in acinus. The expression of caspase- 3 activation is considered an indicator of apoptosis; certolizumab improved Na-taurocholate induced pancreatitis. Free oxygen radicals and neutrophil infiltrations play an important role in the progression of pancreatic injury. ${ }^{23,24}$ In this study, in the certolizumab-treated group, tissue MPO and MDA levels were significantly reduced compared to the untreated group.

Pancreatic tissue damage caused increased levels of serum amylase or lipase and LDH levels. Increase started at the beginning of the first day, and enzyme levels returned to normal over the 5 days. There is a parallel condition at the reduction of pancreatic injury and reduced serum levels of biochemical markers. In our study, in the certolizumab-treated group, amylase, lipase, and serum LDH levels were significantly lower than the group not receiving treatment. Our findings are consistent with the literature.

\section{CONCLUSION}

As a result, certolizumab treatment in a model of necrotizing pancreatitis reduced damage in pancreatic tissue, and serum levels of indicators were significantly improved. To the best of our knowledge, certolizumab has not been used in other studies.

\section{Acknowledgment}

This study was supported by the Scientific Projects Unit of Pamukkale University. We want to thank Dr. Barbaros Sahin DVM, from the Experimental Animal Laboratory.

\section{RESUMO}

OBJETIVO: Os efeitos de Certolizumab, um anticorpo monoclonal pegilado para o fator de necrose tumoral $\alpha$, na pancreatite aguda induzida experimentalmente (PA) foram examinados.

MÉTODO: Trinta e seis ratos Wistar Albino foram divididos aleatoriamente em quatro grupos. O Grupo I foi considerado o grupo controle e não recebeu medicação; o Grupo Il foi o grupo Certolizumab e recebeu $100 \mathrm{ml} / \mathrm{kg}$ de soro fisiológico administrado no ducto biliopancreático e dose única de $10 \mathrm{mg}$ Certolizumab administrada por via intraperitoneal simultaneamente. A pancreatite aguda foi induzida com uma injeção retrógrada de uma solução de 3\% taurocolato de sódio aplicada no ducto biliopancreático comum nos grupos de estudo (Grupo III) e tratamento (Grupos IV). Os ratos foram sacrificados 72 horas depois. As atividades séricas de amilase, lipase, lactato desidrogenase, juntamente com a histopatologia pancreática, foram examinadas.

RESULTADOS: O tratamento com Certolizumab diminuiu significativamente os níveis séricos de amilase, lipase e LDH; edema histopatológico, hemorragia, necrose paranquimatosa, necrose gordurosa e escores de infiltração; atividade imuno-histoquímica de MDA, MPO, TNF- $\alpha$ e Caspase-3.

CONCLUSÃo: Estes resultados suportam a ideia de que o Certolizumab pode ser benéfico para a gravidade da PA.

PALAVRAS-CHAVE: Pancreatite necrosante aguda. Certolizumab Pegol. Ratos.

\section{REFERENCES}

1. Bai Y, Liu Y, jia L, Jiang $H$, Ji M, Lv N, et al. Severe acute pancreatitis in China: etiology and mortality in 1976 patients. Pancreas. 2007;35(3):232-7.

2. Popovic JR, Kozak LJ. National hospital discharge survey: annual summary, 1998. Vital Health Stat 13. 2000;(148):1-194.

3. Peery AF, Dellon ES, Lund J, Crockett SD, McGowan CE, Bulsiewicz W], et al. Burden of gastrointestinal disease in the United States: 2012 update. Gastroenterology. 2012;143(5):1179-87.

4. Grewal HP, Kotb M, el Din AM, Ohman M, Salem A, Gaber L, et al. Induction of tumor necrosis factor in severe acute pancreatitis and its subsequent reduction after hepatic passage. Surgery. 1994;115(2):213-21.

5. Hughes CB, Grewal HP, Gaber LW, Kotb M, El-din AB, Mann L, et al. Anti-TNFalpha therapy improves survival and ameliorates the pathophysiologic sequelae in acute pancreatitis in the rat. Am | Surg. 1996;171(2):27480 .
6. Gramlick A, Fossati G, Nesbitt AM. Neutralization of soluble and membrane tumor necrosis factor-alpha (TNF-alpha) by infliximab, adalimumab, or certolizumab pegol using P55 or P75 TNF-alpha receptor-specific bioassays. Paper presented at: Gastroenterol 2006.

7. Nesbitt A, Fossati G, Bergin M, Stephens P, Stephens S, Foulkes R, et al. Mechanism of action of certolizumab pegol (CDP870): in vitro comparison with other anti-tumor necrosis factor alpha agents. Inflamm Bowel Dis. 2007;13(11):1323-32.

8. Chan YC, Leung PS. Acute pancreatitis: animal models and recent advances in basic research. Pancreas. 2007;34(1):1-14.

9. Schmidt I, Rattner DW, Lewandrowski K, Compton CC, Mandavilli U, Knoefel WT, et al. A better model of acute pancreatitis for evaluating therapy. Ann Surg. 1992;215(1):44-56.

10. Shields CJ, Winter DC, Sookhai S, Ryan L, Kirwan WO, Redmond HP. Hy- 
pertonic saline attenuates end-organ damage in an experimental model of acute pancreatitis. Br J Surg. 2000;87(10):1336-40

11. Yilmaz M, Topsakal S, Herek O, Ozmen O, Sahinduran S, Buyukoglu T, et al. Effects of etanercept on sodium taurocholate-induced acute pancreatitis in rats. Transl Res. 2009;154(5):241-9.

12. Steinberg W, Tenner S. Acute pancreatitis. N Eng | Med. 1994;330(17):1198210.

13. Meek K, Toosie K, Stabile BE, Elbassir M, Murrell Z, Lewis R/, et al. Simplified admission criterion for predicting severe complications of gallstone pancreatitis. Arch Surg. 2000;135(9):1048-52.

14. Frossard JL, Steer ML, Pastor CM. Acute pancreatitis. Lancet 2008;371(9607):143-52.

15. Norman JG, Fink GW, Franz MG. Acute pancreatitis induces intrapancreatic tumor necrosis factor gene expression. Arch Surg. 1995;130(9):966-70.

16. Niederau C, Niederau M, Lüthen R, Strohmeyer G, Ferrell LD, Grendell IH. Pancreatic exocrine secretion in acute experimental pancreatitis. Gastroenterology. 1990;99(4):1120-7.

17. Bragado MJ, San Román II, González A, García LJ, López M, Calvo J. Impairment of intracellular calcium homoeostasis in the exocrine pancreas after caerulein-induced acute pancreatitis in the rat. Clin Sci (Lond). 1996;91(3):365-9.
18. García M, Barbáchano EH, Lorenzo PH, San Román II, López MA, Coveñas $R$, et al. Saline infusion through the pancreatic duct leads to changes in calcium homeostasis similar to those observed in acute pancreatitis. Dig Dis Sci. 2009;54(2):300-8

19. Mahadevan U, Abreu MT. 960 certolizumab use in pregnancy: low levels detected in cord blood. Gastroenterology. 2009;136(5):A146

20. Zhang XP, Lin Q, Zhou YF. Progress of study on the relationship between mediators of inflammation and apoptosis in acute pancreatitis. Dig Dis Sci. 2007;52(5):1199-205.

21. Tsujimoto M, Yokota S, Vilcek |, Weissmann G. Tumor necrosis factor provokes superoxide anion generation from neutrophils. Biochem Biophys Res Commun. 1986;137(3):1094-100

22. Oruc N, Ozutemiz AO, Yukselen V, Nart D, Celik HA, Yuce G, et al. Infliximab: a new therapeutic agent in acute pancreatitis? Pancreas. 2004;28(1):e1-8.

23. Sanfey H, Bulkley GB, Cameron IL. The pathogenesis of acute pancreatitis. The source and role of oxygen-derived free radicals in three different experimental models. Ann Surg. 1985;201(5):633-9.

24. Genovese T, Mazzon E, Di Paola R, Muià C, Crisafulli C, Menegazzi M, et al. Hypericum perforatum attenuates the development of cerulein-induced acute pancreatitis in mice. Shock. 2006;25(2):161-7. 